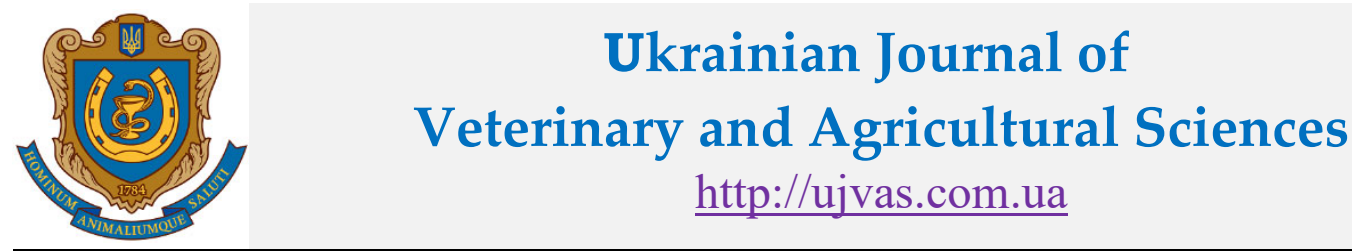

Stepan Gzhytskyi National University of Veterinary Medicine and Biotechnologies Lviv

\begin{tabular}{l|l|l} 
original article & UDC 574.5:639.3(477) $\quad$ doi: 10.32718/ujvas4-3.06
\end{tabular}

\title{
Assessment of ecological conditions for growing the market-size fish in the Kantivka fattening pond (Khmelnychchyna, Ukraine)
}

\author{
T. V. Hryhorenko, L. V. Samchyshyna, N. P. Chuzhma, A. M. Bazaieva, N. M. Savenko, V. P. Oborsky, \\ N. G. Mykhailenko
}

Institute of Fisheries of the National Academy of Agrarian Sciences of Ukraine, Obukhivska 135, Kyiv 03164, Ukraine

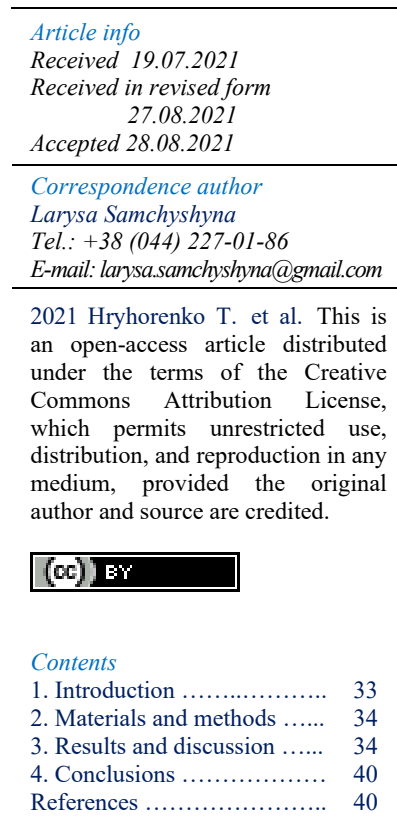

\begin{abstract}
Abiotic (water quality) and biotic (Phyto-, zooplankton and benthos) factors in the Kantivka fattening pond the Khmelnitskrybhosp Private Joint-Stock Company were studied during the vegetation seasons in 2020. The aquaculture objects in the pond are cyprinid fish species (carp, grass carp, silver carp, pike). The ecological conditions of the pond were evaluated as good enough for the fish fattening purpose. The critical water quality parameters were following traditional values accepted for fish farming in Ukraine. The taxonomic composition of plankton and benthos was represented by widespread and Ubiquiti species mainly. The 124 species and intraspecies taxa of microalgae and the 34 species of zooplankton were identified in the Kantivka fattening pond. The mean abundance and biomass for the phytoplankton were 183.8 million cells $/ \mathrm{dm}^{3}$ and $35.61 \mathrm{mg} / \mathrm{dm}^{3}$, respectively; for zooplankton, those were as $336600 \mathrm{ind} / \mathrm{m}^{3}$ and $14.83 \mathrm{~g} / \mathrm{m}^{3}$, and for zoobenthos, those values were as $309.6 \mathrm{ind} / \mathrm{m}^{2}$, and biomass as $5.84 \mathrm{~g} / \mathrm{m}^{2}$. Such parameters of natural forage base correspond to the optimal values for natural fish food according to fish farming standards in Ukraine. In the late summer, the free-living copepod stages and mature adult females of the parasitic copepod crustacean Ergasilus sieboldi Nordmann were registered in plankton. This copepod causes the invasion of fish diseases like infection and destruction of gill arches, which leads to a severe disturbance in fish respiration, emaciation, delaying in growth, and the potential death of commercial fish even. The development of natural fish food in the Kantivka fattening pond is shown an intensive level of biomass and abundance of phytoplankton, zooplankton, and zoobenthos. It is considered sufficient to meet the natural nutritional needs (in combination with artificial feeding) for older age groups of the cultivated cyprinid fish species.
\end{abstract}

Keywords: natural forage base, phytoplankton, zooplankton, benthos, cyprinid fish species, Ergasilus sieboldi.

\section{Citation:}

Hryhorenko T. V., Samchyshyna L. V., Chuzhma N. P., Bazaieva A. M., Savenko N. M., Oborsky V. P., \& Mykhailenko, N. G. (2021). Assessment of ecological conditions for growing the market-size fish in the Kantivka fattening pond (Khmelnychchyna, Ukraine). Ukrainian Journal of Veterinary and Agricultural Sciences, 4(3), 33-41.

\section{Introduction}

Intensification of fisheries aims to meet the growing demand for fish as the world population grows (Burhaz et al., 2019; 2020; Honcharova et al., 2021). Research investigations on sustainable aquaculture practices, raising the intensity of fish growth and increasing a crop while minimizing environmental and social impacts, concerns about how animals are reared, and the environmental impacts of aquaculture have made sustainability more critical for consumers. Aquaculture offers a way to meet global demand while reducing the pressure on wild capture fisheries. The dynamics of fish consumption and its products in Ukraine have constantly grown from $9.6 \mathrm{~kg}$ per person in 2016 to $12.5 \mathrm{~kg}$ in 2019 (Public report..., 2019). At the same time, this number has reached $22 \mathrm{~kg}$ per person in Europe (FAO, 2020).

Water quality parameters are fundamental for both the health and growth of farmed fish species. The main ecologi- cal factors, like temperature, oxygen, chemical, and hydrobiological regimes, directly affect the complexity of production potential and the efficiency of fish farming (Rudenko et al., 2019; Honcharova et al., 2019; Vodianitskyi et al., 2020; Kofonov et al., 2020; Prychepa et al., 2021).

Despite the increase of variety of artificial fish feeds at the Ukrainian market aimed to enhance fishes' growth and gut performance, the natural fish food, namely planktonic and benthic invertebrates, algae, small vertebrates (juvenile fish) is still play great importance. All commercial fish species' fry feeds exclusively on the natural forage base - rotifers, microcrustaceans. E.g., the fry of the one-year yellow perch feeds exclusively on natural food (planktonic and benthic organisms). Thus, this fry weighing 3-5 g feeds on rotifers; at weigh up to $12 \mathrm{~g}$ - the $90 \%$ of gut content is mainly cladocerans and copepods, and fry weighing more than $15 \mathrm{~g}$ is changing from the uptaking the tiny organisms to large (Sharylo et al., 2018). Pike, catfish, pike perch, and 
other fish species popular in Ukrainian aquaculture feed similarly. However, the cyprinid fish species are still the most welcomed by Ukrainian customers.

It is known that the nutritional value of alive natural fish food in regards to nutrient content and amino acid composition of the protein is significantly exceeded the nutritional value of artificial feeds. The leading natural food for cyprinid species in fishing ponds is phytoplankton, zooplankton, and zoobenthos. Fishing ponds are considered more productive if green (chlorococcal) algae dominate the composition of phytoplankton. The zooplankton is by cladoceran and copepod crustaceans, and the zoobenthos is by chironomid larvae (Krazhan \& Khyzhniak, 2014). At the same time, other ecological, environmental conditions like temperature, dissolved oxygen, a chemical regime of Water significantly affect the productive potential and determine the efficiency of fish farming.

Our work aimed to investigate the ecological conditions like qualitative and quantitative parameters of natural forage base of the Kantivka fattening pond (Khmelnytskyi region, Ukraine), the taxonomic composition, abundance, and biomass of Phyto-, zooplankton, and zoobenthos, as well as to monitor the central hydrochemical values of water quality during the warm season.

\section{Materials and methods}

The research was conducted during the 2020 warm season in the Kantivka fattening pond (N $49^{\circ} 60^{\prime}$, E $27^{\circ} 39^{\prime}$ ), located in Pylyavka, Khmelnytcky region, Ukraine. This pond operates by the Khmelnitskrybhosp Private Joint-Stock Company, engaged in cultivating market-size fish, breeding processes, and fry growing. The main focus of the aquaculture in the Kantivka fattening pond is growing the marketsize cyprinid fish species (carp, herbivorous fishes, pike). The area of the pond is about 155 ha, and the average depth is $1.5 \mathrm{~m}$. Hydrochemical and hydrobiological samples were taken in June, August, and September 2020 and analyzed in the Laboratory of ecological researches of IF NAAS according to the generally accepted methods in fish farming (Alekin et al., 1973). The obtained values were compared with the current standard values accepted in fish farming in Ukraine (Voda rybohospodarskyh..., 2006).

Hydrobiological samples were taken simultaneously with hydrochemical ones. Phytoplankton samples as 0.5 liters of water were taken from the upper horizon at a depth of $0.2-0.5 \mathrm{~m}$ in different pond parts: near the top, in the middle, and at the dam and fixed with $4 \%$ formaldehyde. Fixed samples were kept in the dark place for 10-12 days, then concentrated by reverse filtration. The calculation of abundance and biomass of phytoplankton was performed following by Krazhan and Khyzhnyak (2014). Taxonomic identification of planktonic algae is performed under the Micros MC 300 microscope (Austria) followed by Asaul (1973), Topachevsky and Masyuk (1984), Kondratieva (1968).
Zooplankton samples were taken from the different parts of the pond (top, middle, and dam) using a miniature model of the Apstein plankton net (mesh size is № 76), through which 100 liters of Water were filtered. Samples were fixed with $4 \%$ formaldehyde. They were processed and counted following Krazhan and Khyzhnyak (2014). To calculate the biomass, the tables of the wet weight of individuals were used. The species composition of zooplankton was studied under the ULAB microscope (China) using Kutikova (1970), Monchenko (1974), Hudec (2010), Alekseev and Tcalolikhin (2010).

A cylindrical bottom sampler with a square of $0.01 \mathrm{~m}^{2}$ was used for zoobenthos sampling. One sample was included the soil of three dredgers taken from different parts of the pond. Bentos was washed through a sieve with mesh size № 18 and fixed with $4 \%$ formaldehyde. In the Laboratory, the benthic organisms were sorted into systematic groups, counted, and weighed on torsion balance. Then the abundance and biomass of organisms were recalculated as ind $/ \mathrm{m}^{2}$ and $\mathrm{g} / \mathrm{m}^{2}$, relatively. The species composition of organisms was determined under the dissecting microscope MBS-1 using Alekseev and Tcalolikhin (2010), Pankratova (1983), Krazhan and Lupacheva (1991). The photo-, zooplankton and benthos samples were carried out in the Laboratory of Hydrobiology and Technologies of Cultivation of Valuable Invertebrates, IF NAAS.

\section{Results and discussion}

\section{Water quality}

The water temperature in the Kantivka fattening pond was varied from 20 to $28{ }^{\circ} \mathrm{C}$ during the studied seasons. The chemical composition of pond water is of hydro carbonate class by the calcium group and is common for natural waters of Polissya. Water mineralization was varied from 375.0 to $401.7 \mathrm{mg} / \mathrm{dm}^{3}$. The hydrocarbons concentration was $256.3-$ $268.5 \mathrm{mg} / \mathrm{dm}^{3}$, calcium - 42.1-48.1 mg/dm ${ }^{3}$, magnesium $21.9-41.3 \mathrm{mg} / \mathrm{dm}^{3}$, sodium + potassium $-2.8-30.3 \mathrm{mg} / \mathrm{dm}^{3}$, and the total water hardness was $4.0-5.0 \mathrm{mg}-\mathrm{eq} / \mathrm{dm}^{3}$ (Table 1). The $\mathrm{pH}(7.3-7.5)$ and the content of free ammonia $\left(0.02 \mathrm{mg} \mathrm{N} / \mathrm{dm}^{3}\right)$ did not exceed the normal values.

In general, the chemical parameters of the water quality of the Kantivka fattening pond are suitable for aquaculture. Most of the chemical elements were within the normal values adopted for fish farming in Ukraine. We noticed from permanganate oxidation that the content of soluble organic matters in August and September was higher. In September, it increased significantly by 1.8 times, primarily due to the extinction of microalgae and the accumulation of organic matters in the Water. Also, the nitrite values slightly exceeded the acceptable parameters in August and September, but this is not a significant threat for aquaculture. It was an intermediate temporal product of ammonium when it transformed into nitrates due to bacterial activity. A slightly high iron level in the Water $\left(1.43-2.11 \mathrm{mg} / \mathrm{dm}^{3}\right)$ was observed during the monitoring. 
Table 1

Water quality parameters of the Kantivka fattening pond in 2020

\begin{tabular}{|c|c|c|c|c|c|}
\hline \multirow{2}{*}{ № } & \multirow{2}{*}{ Water quality parameters } & \multicolumn{3}{|c|}{ Sampling time, month } & \multirow{2}{*}{$\begin{array}{l}\text { Standard values for } \\
\text { pond water }\end{array}$} \\
\hline & & June & August & September & \\
\hline 1 & Hydrogen ion concentration, $\mathrm{pH}$ & 7.3 & 7.4 & 7.5 & $6.5-8.5$ \\
\hline 2 & Free ammonia, $\mathrm{NH}_{3} \mathrm{mg} \mathrm{N} / \mathrm{dm}^{3}$ & 0.02 & 0.02 & 0.02 & $\leq 0.05$ \\
\hline 3 & Permanganate oxidation, $\mathrm{mg} \mathrm{O} / \mathrm{dm}^{3}$ & 9.6 & 17.9 & 27.2 & $\leq 15.0$ \\
\hline 4 & Bichromate oxidation, $\mathrm{mg} \mathrm{O} / \mathrm{dm}^{3}$ & 24.0 & 44.7 & 68.0 & $\leq 50.0$ \\
\hline 5 & Ammonium nitrogen, $\mathrm{NH}_{4}{ }^{+}, \mathrm{mg} \mathrm{N} / \mathrm{dm}^{3}$ & 2.20 & 1.51 & 1.83 & $\leq 2.0$ \\
\hline 6 & Nitrites, $\mathrm{NO}_{2}^{-}, \mathrm{mg} \mathrm{N} / \mathrm{dm}^{3}$ & 0.06 & 0.11 & 0.14 & $\leq 0.1$ \\
\hline 7 & Nitrates, $\mathrm{NO}_{3}{ }^{-}, \mathrm{mg} \mathrm{N} / \mathrm{dm}^{3}$ & 0.15 & 0.08 & 0.33 & $\leq 2.0$ \\
\hline 8 & Inorganic phosphorus, $\mathrm{PO}_{4}{ }^{3-}, \mathrm{mg} \mathrm{P} / \mathrm{dm}^{3}$ & 0.33 & 0.33 & 0.42 & $\leq 0.7$ \\
\hline 9 & Total iron, $\mathrm{Fe}^{2+}+\mathrm{Fe}^{3+}, \mathrm{mg} \mathrm{Fe} / \mathrm{dm}^{3}$ & 1.63 & 1.43 & 2.11 & $\leq 1.0$ \\
\hline 10 & Calcium, $\mathrm{Ca}^{2+}, \mathrm{mg} / \mathrm{dm}^{3}$ & 42.1 & 48.1 & 42.1 & $\leq 70$ \\
\hline 11 & Magnesium, $\mathrm{Mg}^{2+}, \mathrm{mg} / \mathrm{dm}^{3}$ & 23.1 & 21.9 & 41.3 & $\leq 30$ \\
\hline 12 & Sodium + Potassium, $\mathrm{Na}^{+}+\mathrm{K}^{+}, \mathrm{mg} / \mathrm{dm}^{3}$ & 30.3 & 19.3 & 2.8 & $\leq 50$ \\
\hline 13 & Hydro carbonates, $\mathrm{HCO}_{3}{ }^{-}, \mathrm{mg} / \mathrm{dm}^{3}$ & 268.5 & 256.3 & 256.3 & $\leq 400$ \\
\hline 14 & Chlorides, $\mathrm{Cl}^{-}, \mathrm{mg} / \mathrm{dm}^{3}$ & 22.5 & 20.8 & 25.0 & $\leq 70$ \\
\hline 15 & Sulfates, $\mathrm{SO}_{4}{ }^{2-}, \mathrm{mg} / \mathrm{dm}^{3}$ & 8.6 & 8.6 & 9.5 & $\leq 70$ \\
\hline 16 & Hardness, mg-eq/dm ${ }^{3}$ & 4.0 & 4.2 & 5,0 & $5-7$ \\
\hline 17 & Mineralization, $\mathrm{mg} / \mathrm{dm}^{3}$ & 395.1 & 375.0 & 401,7 & $\leq 1000$ \\
\hline
\end{tabular}

\section{Phytoplankton}

During the vegetative season, the phytoplankton of the Kantivka fattening pond was represented by 124 species and interspecies of algae, which belong to six divisions: Cyanophyta, Euglenophyta, Dinophyta, Bacillariophyta, Chlorophyta, and Chryzophyta.

In June, the phytoplankton was represented by species and interspecies that belonged to the divisions: Euglenophyta, Dinophyta, Bacillariophyta, Chlorophyta, and golden Chryzophyta (Fig. 1a). Cyanophyta were absent. A slight floral diversity characterizes this period. The most notable microalgae species (25) were found at the middle part of the

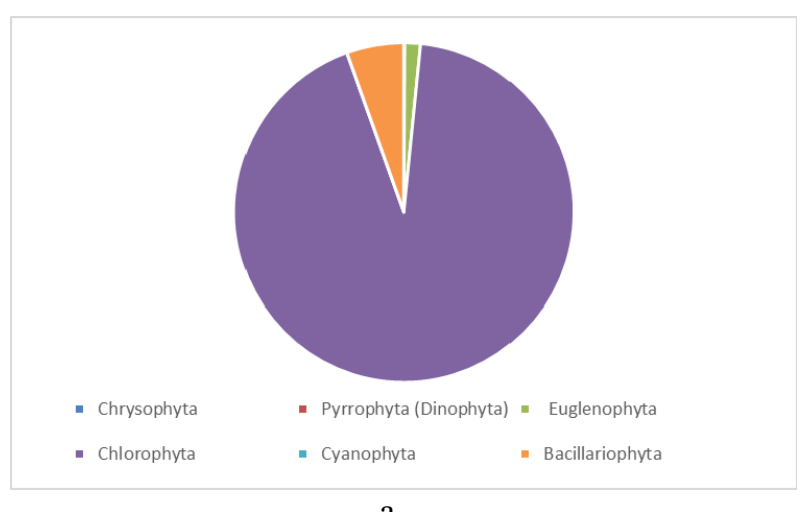

Fig. 1. Relative abundance (a) and relative biomass

In August, phytoplankton was represented by species and intraspecies belonging to Cyanophyta, Euglenophyta, Dinophyta, Bacillariophyta, Chlorophyta, and Chryzophyta. The number of species in the pond was varied from 57 to 60 species at different places. Blue-green algae played the cen- pond and near dams 13 and 16, respectively. The development of phytoplankton in June shows low quantitative values. In different pond places, the abundance of algae was varied from 0.92 million cells $/ \mathrm{dm}^{3}$ to 4.946 million cells $/ \mathrm{dm}^{3}$, and biomass was from $0.57 \mathrm{mg} / \mathrm{dm}^{3}$ to $1.04 \mathrm{mg} / \mathrm{dm}^{3}$. The average for the pond was 3.141 million cells $/ \mathrm{dm}^{3}$, and biomass was $0.87 \mathrm{mg} / \mathrm{dm}^{3}$. The phytoplankton (Fig. $1 \mathrm{a}, \mathrm{b}$ ) was dominated by Chlorophyta (Scenedesmus spp., Ankyra spp.). Their average abundance in the pond was 2.917 million cells $/ \mathrm{dm}^{3}$, and biomass 0.61 $\mathrm{mg} / \mathrm{dm}^{3}$. These phytoplankton values were insufficient to meet the nutritional needs of cultivated fishes.

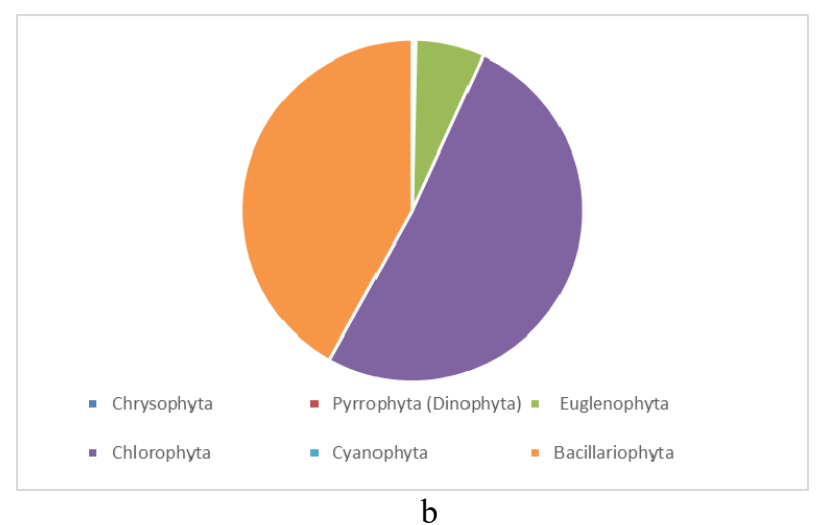

(b) of phytoplankton in the Kantivka fattening pond in June

tral role in forming the number and biomass of planktonic algae, and their contribution to abundance and biomass was $85.9 \%$ and $47.6 \%$, respectively (Fig. 2a, b). Aphanizomenon flos-aquae, Anabaena flos-aquae, Microcystis aeruginosa were the dominant species. 


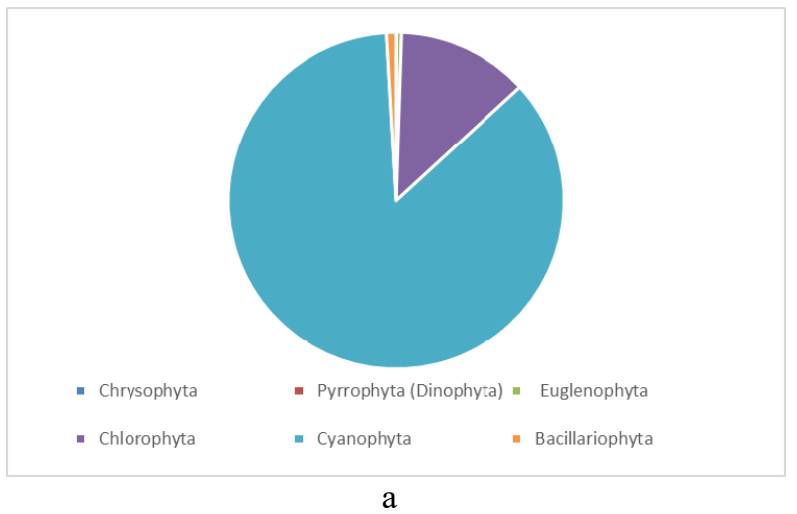

a

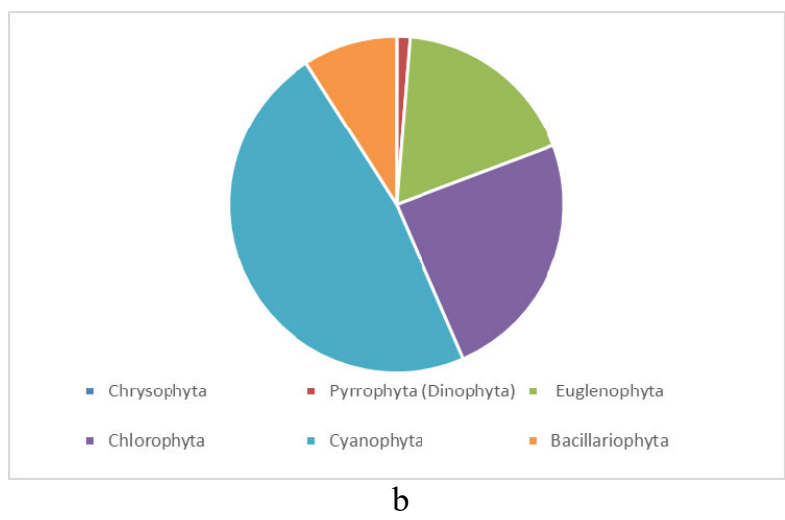

$\mathrm{b}$

Fig. 2. Relative abundance (a) and relative biomass (b) of phytoplankton in the Kantivka fattening pond in August

The mean abundance of phytoplankton was 267 million cells $/ \mathrm{dm}^{3}$, and biomass was $40.96 \mathrm{mg} / \mathrm{dm}^{3}$ in August. The top of the pond was characterized by the highest values of algae development: 325.3 million cells $/ \mathrm{dm}^{3}$ and 50.16 $\mathrm{mg} / \mathrm{dm}^{3}$. Near the dam, the abundance and biomass were slightly lower but were still at the sufficiently high level as 299.2 million cells $/ \mathrm{dm}^{3}$ and $40.83 \mathrm{mg} / \mathrm{dm}^{3}$, respectively. The development of planktonic algae in the middle of the pond was the lowest and is 176.7 million cells $/ \mathrm{dm}^{3}$ by abundance and $31.85 \mathrm{mg} / \mathrm{dm}^{3}$ by biomass.

In September, the composition of the phytoplankton was changed. The green algae, mainly chlorococcal, again have

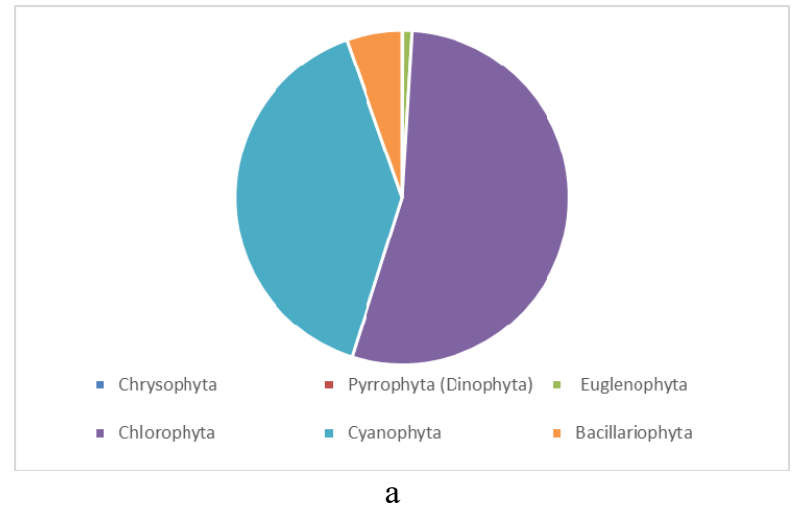

Fig. 3. Relative abundance (a) and relative biomass (b)

Hence, during the studying period, the abundance and biomass of phytoplankton in the Kantivka fattening pond were formed mainly due to the vegetation of green algae. The average phytoplankton abundance and biomass parameters were 183.8 million cells $/ \mathrm{dm}^{3}$ and $35.61 \mathrm{mg} / \mathrm{dm}^{3}$, respec- become dominant. Thus, the contribution of green algae in the phytoplankton was $54 \%$ by abundance. Blue-green algae were subdominant contributing around $41 \%$ by abundance. However, the formation of biomass in this period was significantly influenced by euglena algae. The total abundance of phytoplankton in September was 281.16 million cells $/ \mathrm{dm}^{3}$, and biomass $-64.99 \mathrm{mg} / \mathrm{dm}^{3}$, which indicates the highest development values of phytoplankton in this pond. In September, the dominant complex of phytoplankton species has included taxa of the genera Dictyosphaerium, Scenedesmus, Closterium, Microcystis, Trachelomonas.

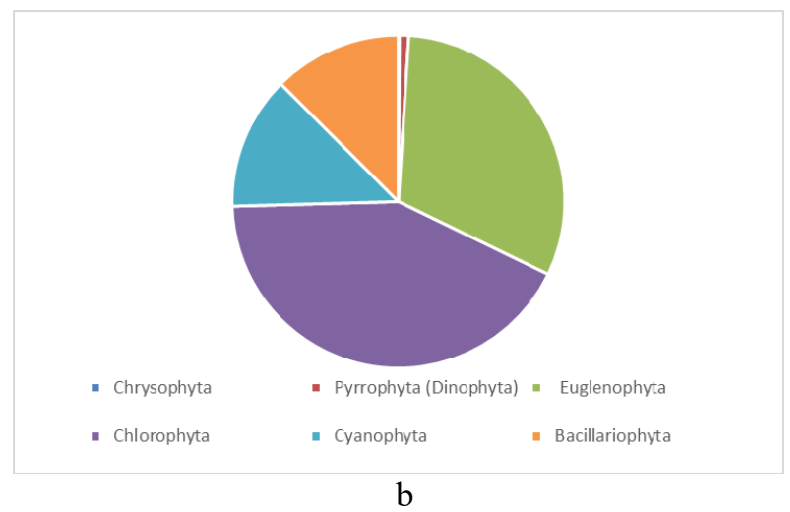

b

Table 2

Biomass values of the natural forage base in the Kantivka fattening pond in 2020 warm season $(M \pm m, n=6)$

\begin{tabular}{lccc}
\hline \multirow{2}{*}{ Parameters } & \multicolumn{3}{c}{ Hydrobiological communities } \\
\cline { 2 - 4 } & Phytoplankton, $\mathrm{mg} / \mathrm{dm}^{3}$ & Zooplankton, $\mathrm{g} / \mathrm{m}^{3}$ & Zoobenthos, $\mathrm{g} / \mathrm{dm}^{2}$ \\
\hline Averaged values & $35.61 \pm 18.70$ & $14.83 \pm 4.47$ & $5.84 \pm 2.65$ \\
Optimal values for fattening ponds & $25.0-30.0$ & $8.0-12.0$ & $2.0-5.0$ \\
\hline
\end{tabular}

\section{Zooplankton}

We identified the seven species of rotifers, 13 species of cladoceran, and ten species of copepod crustaceans, single ostracods, and insect larvae in the zooplankton of the tively, during the warm season (Table 2). These values of phytoplankton development are sufficient to meet the nutritional needs of cultivated filter-feeding fish species in combination with artificial feeds. 
Table 3

Taxonomical composition of zooplankton in the Kantivka fattening pond

\begin{tabular}{|c|c|c|c|}
\hline \multirow{2}{*}{ Species } & \multicolumn{3}{|c|}{ Sampling time, month. } \\
\hline & June & August & September \\
\hline \multicolumn{4}{|l|}{ ROTIFERA } \\
\hline Asplanchna priodonta Gosse, 1850 & + & + & + \\
\hline Brachionus calyciflorus Pallas, 1766 & & + & + \\
\hline B. angularis Gosse, 1851 & & & + \\
\hline B. diversicornis (Daday, 1883) & + & + & + \\
\hline Keratella cochlearis (Gosse, 1851) & + & + & + \\
\hline Trichocerca pusilla Jennings, 1903 & & + & \\
\hline Polyarthra vulgaris Carlin, 1943 & & + & + \\
\hline \multicolumn{4}{|l|}{ CLADOCERA } \\
\hline Diaphanosoma brachyuran (Lievin,1848) & & & + \\
\hline D. dubia Manuilova, 1964 & & + & \\
\hline Daphnia longispina (O.F. Muller, 1785) & & + & + \\
\hline D. Magna (Straus, 1820) & + & & + \\
\hline D. hyalina-galeata complex & + & & + \\
\hline Ceriodaphnia quadrangular (O.F. Muller, 1785) & & + & + \\
\hline Simocephalus vetulus (O.F. Muller, 1776) & + & & \\
\hline Bosmina longirostris (O.F. Muller, 1785) & & + & + \\
\hline Moina rectirostris Leydig, 1860 & & + & + \\
\hline M. micrura Kurz, 1875 & & + & \\
\hline Chydorus sphaericus (O.F. Muller, 1785) & + & & + \\
\hline Leptodora kindtii (Focke, 1844) & & & + \\
\hline \multicolumn{4}{|l|}{ COPEPODA } \\
\hline Eudiaptomus gracilis Sars, 1873 & + & + & + \\
\hline Cyclops abyssorum Sars, 1873 & + & + & + \\
\hline C. vicinus Uljanin, 1875 & + & & \\
\hline C. bohateri Kozminski, 1933 & & + & \\
\hline Eucyclops serrulatus (Fischer, 1851) & & & + \\
\hline Acanthocyclops trajani Mirabdullayev and Defaye, 2004 & + & + & + \\
\hline Diacyclops bicuspidatus (Claus, 1857) & & & + \\
\hline Mesocyclops leuckarti (Claus, 1857) & + & + & + \\
\hline Thermocyclops oithonoides (Sars G.O., 1863) & + & + & + \\
\hline Ergasilus sieboldi Nordmann, 1832 & & + & \\
\hline Copepodid stages & + & + & + \\
\hline Nauplii & + & + & \\
\hline Ostracoda & + & + & \\
\hline \multicolumn{4}{|l|}{ Insecta } \\
\hline Chironomidae larvae and pupa & + & & \\
\hline Ephemeroptera larvae & + & & \\
\hline
\end{tabular}

At the beginning of summer, zooplankton was represented mainly by crustaceans (Fig. 4, a): copepodids of cyclopoid and calanoid copepods, nauplii, and neonatal stages of cladocers were observed. In June, it should be noted that zooplankton was also mainly represented by numerous larvae of chironomids, Ephemeroptera, and beetles of different developmental stages.

The total abundance of zooplankton in different parts of the pond in June was varied from 15000 up to $40000 \mathrm{and} / \mathrm{m}^{3}$, and biomass was $2.50-11.78 \mathrm{~g} / \mathrm{m}^{3}$. Cladoceran crustaceans were contributed $96.3 \%$ into abundance, while copepods were contributed $59.2 \%$ into biomass. In August, with increasing the water temperature, the structure of zooplankton groups was changed, and the dominant group as for abundance (up to $66.2 \%$ ) as well as for biomass $(79.3 \%)$ have become cladoceran crustaceans (Fig. 4, b). Their abundance reached $325000 \mathrm{ind} / \mathrm{m}^{3}$, and biomass $16.93 \mathrm{~g} / \mathrm{m}^{3}$, mainly due to the development of big-sized species like Daphnia Magna, D. hyalina-galeata complex, D. longispina. In August, zooplankton's total abundance and biomass were $490700 \mathrm{ind} / \mathrm{m}^{3}$ and $21.36 \mathrm{~g} / \mathrm{m}^{3}$, respectively, showing the highest values for the entire studying period.

As the water temperature decreased in autumn, the composition of zooplankton in the pond was changed again. Even though the total abundance of zooplankton has remained at the same level as $494000 \mathrm{ind} / \mathrm{m}^{3}$, the number of thermophilic crustaceans decreased sharply (approximately twice), and zooplankton became dominated by rotifers, mainly contributing $51 \%$ by abundance. Brachionus diversicornis, Br. calyciflorus, and Asplanchna priodonta were the main species. However, these are tiny organisms, and their contribution to zooplankton biomass was insignificant (Fig. 4, e). Cold endothermic species of copepods, such as Diacyclops bicuspidate, have appeared in the Water. 

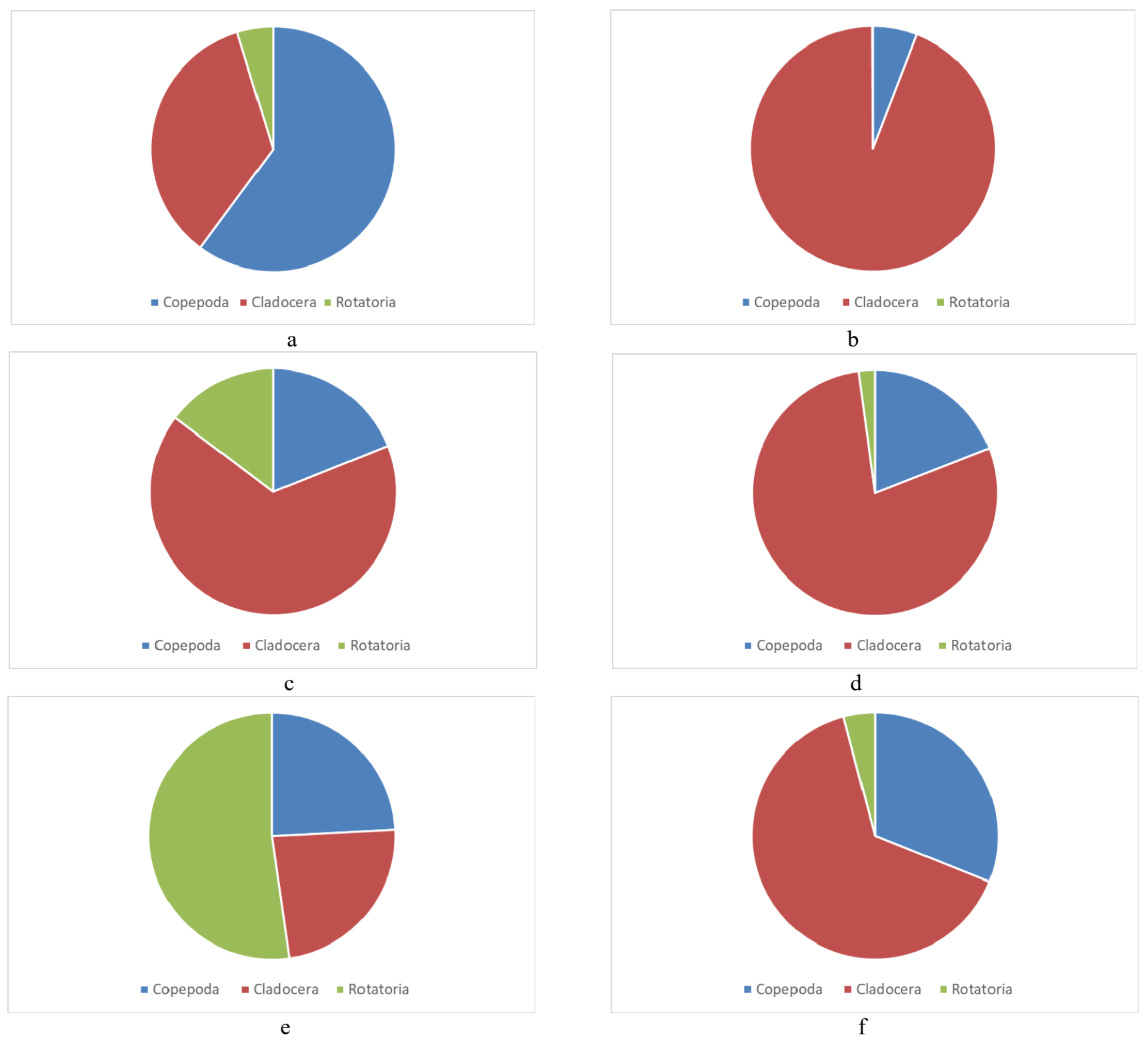

Fig. 4. Relative abundance (a, c, e) and relative biomass (b, d, f) of zooplankton in the Kantivka fattening pond in June (a, b), August (c, d), and September (e, f)

The average biomass of zooplankton in September was $16.86 \mathrm{~g} / \mathrm{m}^{3}$. Despite the high abundance of other taxa (Fig. 4, a, b, c), still, a decisive contribution to the biomass of zooplankton throughout the warm season was made by the large species of cladoceran crustaceans (Fig. 4, d, d, e), such as Leptodora kindtii, Daphnia Magna, D. galeatahyalina complex, Diaphanosoma brachyurum. It should be noted that crustaceans are an important natural food source for young and adults of many fish species (Krazhan \& Lupachova, 1991). Plankton-eating fishes (e.g., bighead carp) consume large quantities of daphniids, moins, bosmins. Quantitative parameters of the development of this group of crustaceans can indicate the level of productivity of fish ponds and the quality of water in the reservoir.

The mean values of the abundance and biomass of zooplankton in the Kantivka fattening pond during the entire studying period were $336600 \mathrm{ind} / \mathrm{m}^{3}$ and $14.83 \mathrm{~g} / \mathrm{m}^{3}$, respectively (Table 2), and corresponded to the optimal developmental parameters to meet the nutritional needs of cultivated cyprinid fish species in combination with artificial feeding.

\section{Zoobenthos}

During the studying period, the benthic fauna of the Kantivka fattening pond mainly consisted of larvae and pupae of mosquitoes from the family Chironomidae, larvae of midges (Heleidae larvae), oligochaetes, and nematodes.

Quantitative parameters of zoobenthos development were the highest in June when the abundance in different parts of the pond was varied in the range of 440 $760.1 \mathrm{and} / \mathrm{m}^{2}$, and as for biomass was $9.68-12.67 \mathrm{~g} / \mathrm{m}^{2}$ and averaged over the pond, respectively $551.1 \mathrm{and} / \mathrm{m}^{2}$ and $10.85 \mathrm{~g} / \mathrm{m}^{2}$. In this case, the abundance $(87.9 \%)$ and biomass $(94.5 \%)$ of zoobenthos were formed due to the development of effective forms of chironomid larvae - Chironomus plumosus, Ch. f. l. semireductus, Ch. thummi (Fig. 5). Further, there was a decrease in the quantitative parameters of zoobenthos development, Thus, in August, the total mean abundance in the pond was at the level of $211.1 \mathrm{and} / \mathrm{m}^{2}$, and biomass $-4.84 \mathrm{~g} / \mathrm{m}^{2}$, and in September $-166.6 \mathrm{and} / \mathrm{m}^{2}$ and $1.83 \mathrm{~g} / \mathrm{m}^{2}$ indicating the active feeding of fishes by benthic forms. It should be noted that in August, the abundance $(84.2 \%)$ and biomass $(96.5 \%)$ of benthic fauna were creat- 
ed due to the development of chironomid larvae; in September, oligochaetes were predominated $(80.0 \%)$ by abundance, while chironomid larvae $(82.0 \%)$ by biomass.

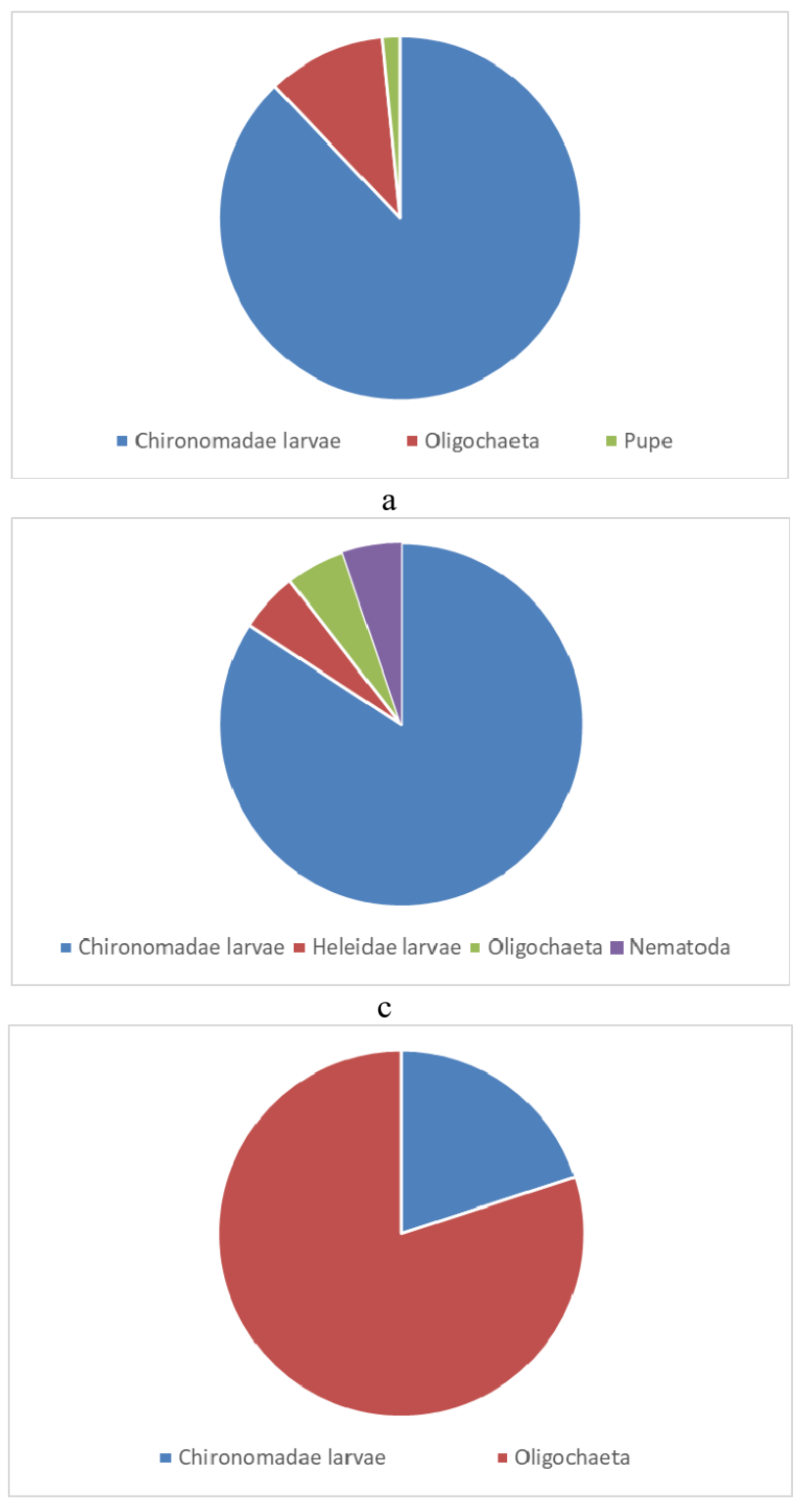

e
So, during the studying period, the average abundance of zoobenthos in the pond was $309.6 \mathrm{ind} / \mathrm{m}^{2}$ and biomass $5.84 \mathrm{~g} / \mathrm{m}^{2}$ (Table 2), corresponding to the optimal developmental values according to fish farming standards.

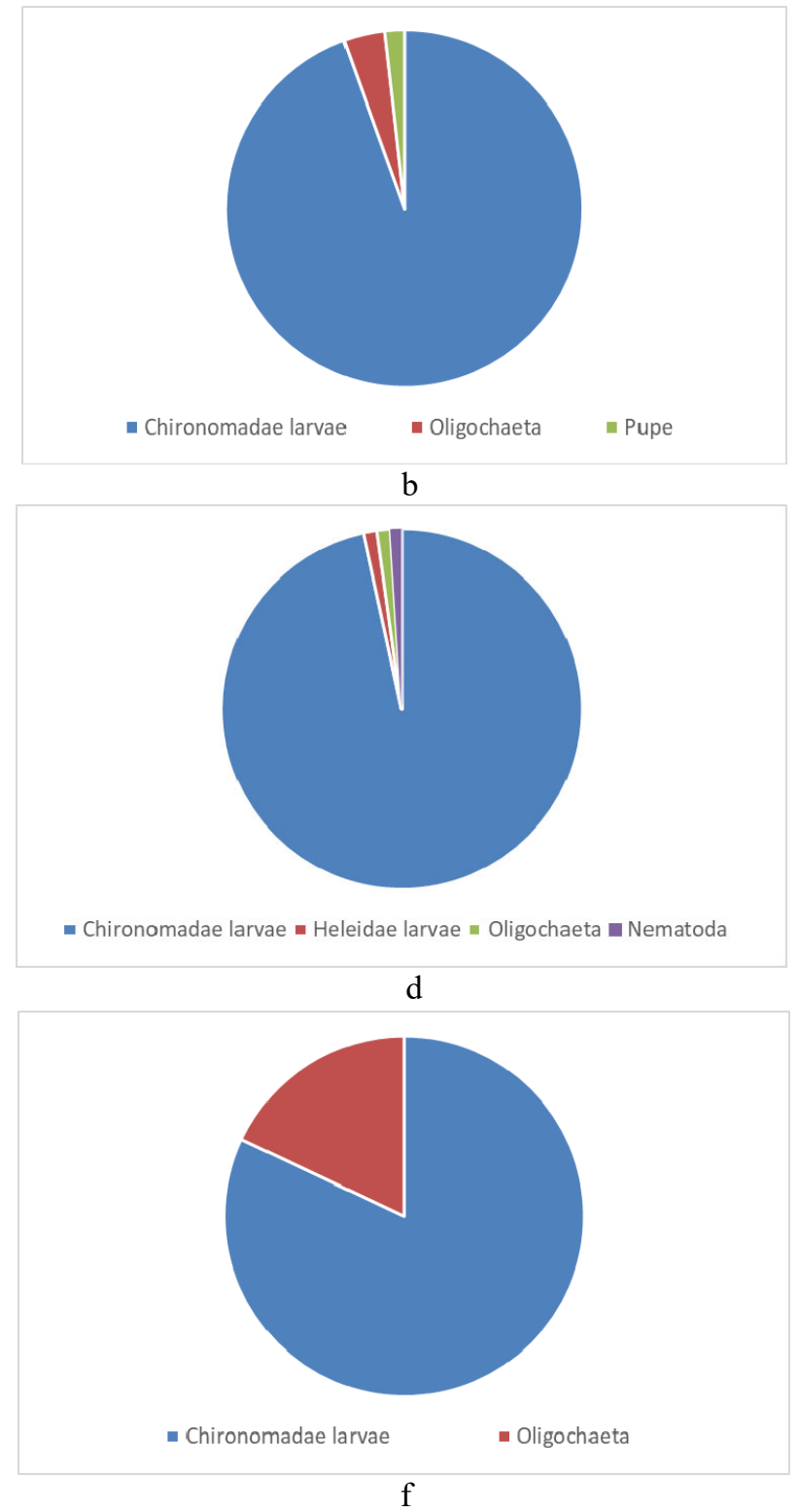

Fig. 5. Relative abundance (a, c, e) and relative biomass (b, d, f) of zoobenthos in the Kantivka fattening pond in June (a, b),

August (c, d), and September (e, f)

Parasitic zooplankton crustaceans caused invasive fish diseases.

Among the ten copepod crustaceans noted in the plankton of the Kantivka fattening pond, the eight taxa are intermediate hosts of parasitic pathogens of fish diseases. Thus, for Cyclops vicinus, a cold-endothermic species that we observed in the spring in the Kantivka pond, about 15 species of helminths are known. For T. oithonoides and $M$. leuckarti, these numbers are 37 and 68 species of helminths from the classes of cestodes and scrapers (Monchenko, 1974). The diaptomid calanoid copepod Eudiaptomus gracilis showed the most significant susceptibility to parasitic infection by oncospheres of fish parasite Ligula intestinalis, a common and widespread pseudophyllidean cestode being strongly pathogenic for many freshwater fish populations throughout Europe (Dubinina, 1980). Of course, not all of these species of helminths are represented in the fauna of the Kantivka pond. However, some of these helminths are undoubtedly present at different stages of their developmental cycle in planktonic crustaceans as intermediate hosts and parasitize in the intestines of fishes, ducks, and other aquatic domestic wild birds that inhabit and visit this pond.

In August, free-living stages of the parasitic crustacean Ergasilus sieboldi Nordmann, 1832 were observed in the plankton of the Kantivka pond with an abundance of 30 $\mathrm{ind} / \mathrm{m}^{3}$. The peculiarity of this species is that only the adult females parasitize on fish (Fig. 6). They are attached by the second pair of harpoon-shaped antennae and live in the gills, feeding on the blood and gill tissue of the fish. These parasites are visible on the fish gills in white dots with sizes up to $2 \mathrm{~mm}$. In case of heavy invasion, fishes suffer from difficulties with breathing, delay in growing, which sometimes can cause death (Figurkov, 2016). The massive appearance 
of this species in nature occurs in July-August, while it reproduces and nauplii appear in May.

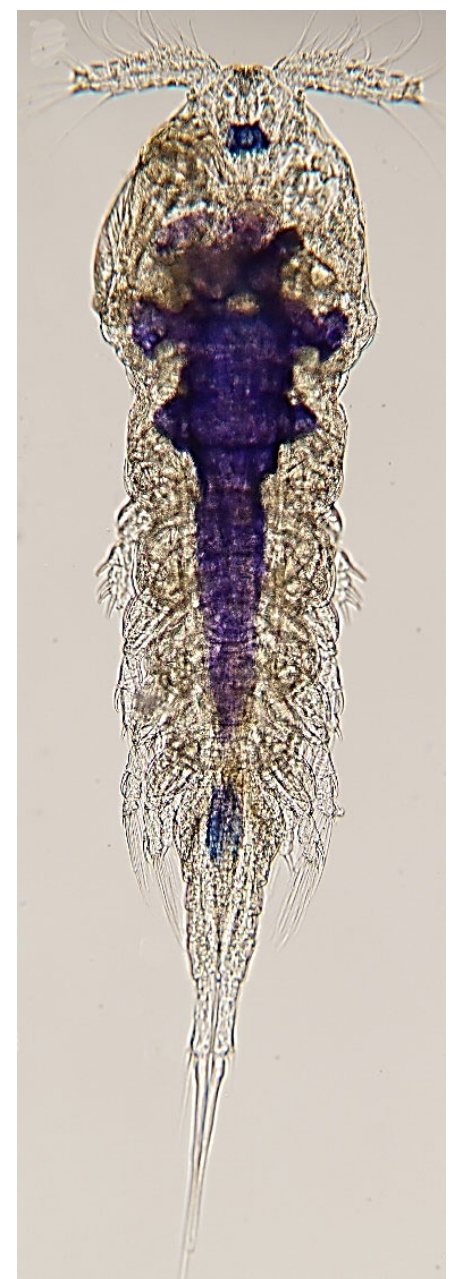

Fig. 6. Adult female of Ergasilus sieboldi (Photo by L. Samchyshyna)

Ergasilus includes species with high pathogenic potential, responsible for significant mortality among cultured fishes in freshwater and brackish environments (Lin \& Ho, 1998; Piasecki et al., 2004). It was estimated that the parasite numbers in the overwintered fish stock in the Rutland Water reservoir were approximately 12 million in April 2003, 8.3 million in April 2004, and 1.2 million in April 2005. Ergasilus sieboldi can cause high mortality in tench, trout, and carp fish farms (Dogel, 1933).

Ergasilus can be treated successfully with a combination of $0.5 \mathrm{ppm}$ copper sulfate and $0.2 \mathrm{ppm}$ ferric sulfate for 6 to 9 days. A $3 \%$ salt dip, followed by $0.2 \%$ prolonged both for three weeks (Arya et al., 2015). Medical treatment of fish invasion by Ergasilus can also be carried out with disinfectants Javel-Clyde (France) or Diamond (Institute of Veterinary Medicine NAAS, Ukraine) following the guidelines of Matvienko and Oliynyk (2013).

As general recommendations for aquaculture management in the Kantivka fattening pond are reducing the number of overwintering fishes. However, the best control method is not to introduce and move infected fish from this pond into other "healthy" fish ponds.

\section{Conclusions}

Ecological conditions of the Kantivka fattening pond were generally favorable for the growth of commercial cyprinid species of fishes. The water temperature was varied in the range of $22-28{ }^{\circ} \mathrm{C}$. The hydrochemical regime of the pond is well managed. Most of the chemical parameters were within the typical values adopted in fish farming in Ukraine.

According to the level of development of phytoplankton, zooplankton, and zoobenthos, the pond can be classified as high-feeding. The fact that plankton contains parasitic forms of copepod crustaceans of Ergasilus genera should aware fish farmers against the introduction of infected fish from the Kantivka pond to other "healthy" reservoirs. It is recommended to decrease the abundance of overwintering fishes in the pond and organize periodical observation of health/gill tissue/fishes in the pond to monitor the population dynamics of parasitic crustaceans in zooplankton.

\section{Acknowledgments}

The authors are grateful to Prof. A. Kotov and Prof. N. Korovchinsky (IPEE RAS) for taxonomic advice on cladoceran crustaceans and Dr. Argun Özak (University of Cukurova, Turkey) for his kind help with parasitic copepod identification. We thank Dr. L. Svetlichny (IZAN NASU) for assistance with photo equipment.

\section{Author contributions}

Conceptualization: T. Hryhorenko; processing and analysis of data: L. Samchyshyna, N. Chuzhma, A. Bazaieva, N. Mykhailenko; writing-original draft preparation: L. Samchyshyna, N. Chuzhma, T. Hryhorenko; supervision: N. Savenko, V. Oborsky. All authors have read and agreed to the published version of the manuscript.

\section{Conflict of interest}

The authors declare that there is no conflict of interest.

\section{References}

Alekin, O. A., Semenov, A. D., \& Scopintcev, B. A. (1973). Rukovodstvo po himicheskomu analizu vod sushi [Guidelines for chemical analyses of inland waters]. Hydrometeoizdat, Leningrad (in Russian).

Alekseev, V. R., \& Tcalolikhin, C. Ya. (2010). Opredelitel zooplankton i zoobentosa presnyh vod evropeiskoi Rosii [Key to zooplankton and zoobenthos of European Russian fresh waters]. Tovaristctestvo nauchnyh issledovanii, Moscow (in Russian).

Arya, R. L., Arya S., Arya R., \& Kumar, J. (2015). Fundamentals of Agriculture (Agri.-Bank) By Scientific Publishers, Jodhpur, Rajasthan.

Asaul, Z. I. (1975). Vyznachnyk evglenovich vodoroslej Ukrainskoy R.S.R. [Key to euglenoid algae]. Naukova Dumka, Kyiv (in Ukrainian).

Borutzky, E. V., Stepanova, L. A., \& Kos, M. S. (1991). Opredelitel Calanoida Presnykh Vod SSSR. [Key to freshwater Calanoida of the USSR]. Nauka, St. Petersburg (in Russian).

Burgaz, M., Matvienko, T., Bezik, K., \& Soborova, O. (2019). The current state of fish market in Ukraine. Ukrainian Journal of Veterinary and Agricultural Sciences, 2(3), 6-10. DOI: 10.32718/ujvas2-3.02.

Burhaz, M., Matviienko, T., Soborova, O., Bezyk, K., Kudelina, O., \& Lichna, A. (2020). Modern state of fish and fishery products export in Ukraine. Ukrainian Journal of Veterinary and Agricultural Sciences, 3(1), 21-26. DOI: 10.32718/ujvas3-1.04. 
Dogel, V. A. (1933). The research problem of fish parasitofauna [Methodology and problems of ichthyoparasitological studies]. Trans. Leningr. Soc. Nat., 62(3), 247-268 (in Russian).

Dubinina, M. N. (1980). Tapeworms (Cestoda, Ligulida) of the fauna of the USSR. Amerind, New Delhi.

FAO (2020). The State of World Fisheries and Aquaculture 2020. Sustainability in action. Rome, 1-244. [Electronic resource]: Mode of access: http://www.fao.org/documents/card/en/c/ ca9229en (viewed on 10.07.2021). Title from the screen.

Figurkov, S. A. (2016). Rol i znachenie nizshyh rakoobraznyh i prochih gidrobiontov (perenoschiki i vozbuditeli zabolevanii) $\mathrm{v}$ zhizni ryb v estestvennyh i iskustvennyh biotcenozah [Role and importance of crustaceans and others hydrobionts (carriers of infections) for fishes in natural and artificial reservoirs. Materialy konferentcii Kontinentalnaia akvakultura: otvet vyzovam vremeni, 2, 351-359 (in Russian).

Honcharova, O. V., Paraniak, R. P., Kutishchev, P. S., Paraniak, N. M., Hradovych, N. I., Matsuska, O. V., Rudenko, O. P., Lytvyn, N. A., Gutyj, B. V., \& Maksishko, L. M. (2021). The influence of environmental factors on fish productivity in small reservoirs and transformed waters. Ukrainian Journal of Ecology, 11(1), 176-180. DOI: 10.15421/2021_27.

Honcharova, O. V., Paranjak, R. P., \& Gutyj, B. V. (2019). Functional state of an organism of freshwater fish under the influence of abiotic factors. Scientific Messenger of Lviv National University of Veterinary Medicine and Biotechnologies. Series: Agricultural sciences, 21(90), 82-87. DOI: 10.32718/nvlvet-a9014.

Hudec, I. (2010). Anomopoda, Ctenopoda, Haplopoda, Onychopoda (Crustacea: Branchiopoda). Fauna Slovenska III - Bratislava: VEDA, Bratislava.

Kofonov, K., Potrokhov, O., Hrynevych, N., Zinkovskyi, O., Khomiak, O., Dunaievska, O., Rud, O., Kutsocon, L., Chemerys, V., Gutyj, B., Fijalovych, L., Vavrysevych, J., Todoriuk, V., Leskiv, K., Husar, P., \& Khumynets, P. (2020). Changes in the biochemical status of common carp juveniles (Cyprinus carpio L.) exposed to ammonium chloride and potassium phosphate. Ukrainian Journal of Ecology, 10(4), 137-147. DOI: $10.15421 / 2020181$

Kondratieva, N. V. (1968). Vyznachnyk prisnyh vodorostej Ukrainskoi RSR vodorosti [Key to freshwater algae of Ukrainian SSR. Blue-green algae]. Naukova dumka, Kyiv (in Ukrainian).

Kutikova, L. A. (1970). Kolovratki fauny SSSR [Rotifers of the fauna of the USSR]. Nauka, Moscow (in Russian).

Krazhan, S. A., \& Khyzhniak, M. I. (2014). Pryrodna kormova baza rybohospodarkykh vodoim: navchalnyi posibnyk. K.: Ahrarna osvita. URL: https://nubip.edu.ua/sites/default/files/u104/ ПОСІБНИК.pdf (in Ukrainian).

Krazhan, S. A., \& Lupacheva, L. I. (1991). Estestvennaja kormovaja baza vodoemov i metody ee opredelenija pri intensivnom vedenii rybnogo hozjajstva (spravochnyj material dlja rabotnikov prudovyh hozjajstv). L'vov (in Russian).

Lin, C. L., \& Ho, J. S. (1998). Two new species of ergasilid copepods parasitic on fishes cultured in brackish Water in Taiwan. Proceedings of the Biological Society of Washington, 111(1), 15-27. URL: https://www.infona.pl/resource/bwmeta1.element.elsevier70c36fe8-db6f-33c7-b9e2-35d550d48503.

Manuilova, E. F. (1964). Vetvistousye rachki (Cladocera) fauny SSSR [Cladocera (Cladocera) fauna of the USSR] Nauka, M.L. (in Russian).

Matvienko, N. M., \& Oliynyk, O. B. (2013). Metodychni rekomendatcii zastosuvannia preparative Zavel-Kleid ta Diamant pry urazhenni koropovyh ryb zbudnykamy krustacenoziv [Methodical recommendations to use the "Javel-Clyde" and "Diamond" drugs treating carp fish crustacean invasions. Institute of Fisheries of NAAS of Ukraine, Kyiv (in Ukrainian).
Monchenko, V. I. (1974). Tstcelepopodibni rakopodibni ([Cyclopidae) Gnathostome cyclopoids (Cyclopidae)]. Fauna of Ukraine. Naukova Dumka, Kiev (in Ukrainian).

Pankratova, V. Ya. (1983). Lichinki i kukolki Komarov podsemeistva Chironomidae fauna SSSR [Larvae and pupa of Chironomidae subfamily of the fauna of USSR]. Nauka, Leningrad (in Russian).

Piasecki, W., Goodwin, A. E., Eiras, J. C., \& Nowak, B. F. (2004). Importance of Copepoda in freshwater aquaculture. Zoological Studies, 43, 193-205.

Prychepa, M., Hrynevych, N., Martseniuk, V., Potrokhov, O., Vodianitskyi, O., Khomiak, O., Rud, O., Kytsokon, L., Sliusarenko, A., Dunaievska, O., Gutyj, B., Pukalo, P., Honcharenko, V., Yevtukh, L., Bozhyk, L., Prus, V., \& Makhorin, H. (2021). Rudd (Scardinius Erythrophthalmus 1., 1758) as a bioindicator of anthropogenic pollution in freshwater bodies. Ukrainian Journal of Ecology, 11(2), 253-260. DOI: 10.15421/2021 108.

Public report of the State Fisheries Agency of Ukraine (2019). [Electronic resource]: Mode of access: https://darg.gov.ua/_publichnij_zvit_derzhavnogo_0 0 _ 049463 1.html (viewed on 12.07.2021). Title from the screen.

Rudenko, O. P., Paranjak, R. P., Kovalchuk, N. A., Kit, L. P., Hradovych, N. I., Gutyj, B. V., Kalyn, B. M., Sukhorska, O. P., Butsiak, A. A., Kropyvka, S. I., Petruniv, V. V., \& Kovalska, L. M. (2019). Influence of seasonal factors on carp fish immune reactivity. Ukrainian Journal of Ecology, 2019, 9(3), 168-173. URL: https://www.ujecology.com/abstract/influence-of-seasonal-factorson-carp-fish-immune-reactivity-44508.html.

Sharyl, Yu. E., Vdovenko, N. M., Dmytryshyn, R. A., Shepelev, S. S., Pavlenko, M. M. et al. (2018). Practychni rekomendatcii tstcodo vyrobnytctva smugastogo okunia $\mathrm{v}$ umovah orientatcii ekonomiky a Kvitova standard bezpeky ta yakosti: naukovo-metodychni rekomendatcii [Practical guide for the growing of the yellow perch at the economic transmission to international standards of safety and quality: research and methodological reccommendations]. Vydavnychii dom Konkord, Kyiv (in Ukrainian).

Tcarenko, P. M. (1990). Kratkii opredelitel chlorokokkovyh vodoroslei Ukrainskoi SSR [Brief key of Chlorococcum algae of Ukrainian SSR]. Naukova Dumka, Kyiv (in Russian).

Tildesley, A. S. (2008) Investigations into Ergasilus sieboldi (Nordmann 1832) (Copepoda: Poecilostomatoida), in a large reservoir rainbow trout fishery in the $\mathrm{UK}$. $\mathrm{PhD}$ thesis, University of Stirling, UK.

Topachevskij, A. V., \& Masjuk, N. P. (1984). Presnovodnye vodorosli Ukrainskoj SSR. K.: Vishha shkola (in Russian).

Voda rybohospodarskyh pidpryemstv. Zagalni vymogy ta normy: COY-05.01.-37-385:2006. (2006). [Water of fisheries companies. General requests and standards: COY-05.01.-37385:2006]. Ministry of Agrarian Policy of Ukraine, Kyiv (in Ukrainian).

Vodianitskyi, O., Potrokhov, O., Hrynevych, N., Khomiak, O., Khudiyash, Y., Prysiazhniuk, N., Rud, O., Sliusarenko, A., Zagoruy, L., Gutyj, B., Dushka, V., Maxym, V., Dadak, O., \& Liublin, V. (2020). Effect of reservoir temperature and oxygen conditions on the activity of Na-K pump in embryos and larvae of perch, roach, and ruffe. Ukrainian Journal of Ecology, 10(2), 184-189. DOI: 10.15421/2020 83.

Krazhan, S. A., \& Khyzhniak, M. I. (2014) Pryrodna kormova baza prudiv [Natural forage base of the ponds]. Old-Plus, Kherson (in Ukrainian).

Krazhan, S. A., \& Lupacheva, L. I. (1991). Pryrodnaia kormovaia baza vodoim i metody ee opredeleniia pri intensivnom vedenii rybnogo hoziaistva [Natural forage base of reservoirs and methods of its determination at intensive aquaculture]. Oblasnaia tipografiia, Lviv (in Russian). 